\title{
SPOŁECZNE I HISTORYCZNE UWARUNKOWANIA WOJEN BIOLOGICZNYCH I EPIDEMII
}

\section{SOCIAL AND HISTORICAL DETERMINANTS OF BIOLOGICAL WARS AND EPIDEMICS}

\author{
Marcin Weiner $^{1(A, B, C, D, E, F, G)}$, Karolina Tarasiuk ${ }^{1(A, B, C, D, E, F)}$
}

${ }^{1}$ Państwowa Szkoła Wyższa im. Papieża Jana Pawła II w Białej Podlaskiej

Weiner, M., Tarasiuk, K. (2018). Społeczne i historyczne uwarunkowania wojen biologicznych i epidemii. Rozprawy Społeczne, 12(3), $20-28$. https://doi.org/10.29316/rs.2018.30

Wkład autorów:

A. Zaplanowanie badań

B. Zebranie danych

C. Dane - analiza i statystyki

D. Interpretacja danych

E. Przygotowanie artykułu

F. Wyszukiwanie i analiza

literatury

G. Zebranie funduszy

Tabele: 0

Ryciny: 0

Literatura: 33

Otrzymano: marzec 2017

Zaakceptowano: maj 2017

\section{Streszczenie}

W prezentowanym artykule przedstawiono przykłady użycia broni biologicznej od czasów starożytności do początków XXI wieku oraz znaczenie epidemii dla rozwoju i upadku poszczególnych cywilizacji i państw. Wykazano, że zarówno w czasach, gdy nie znano etiologii chorób zakaźnych jak i we współczesności, w dobie rozwoju mikrobiologii, genetyki i biologii molekularnej, użycie broni biologicznej może przyczynić się do odniesienia zwycięstwa bardziej, niż użycie broni o charakterze konwencjonalnym.

Słowa kluczowe: wojna biologiczna, epidemia, terroryzm, dżuma, ospa, wąglik

\section{Summary}

This article describes the use of biological weapons from antiquity to the beginning of the 21st century and the importance of epidemics for the development and collapse of civilisations and states. It has been shown that both at a time when the etiology of infectious diseases was not known and in the modern world of microbiology, genetics and molecular biology development, the use of biological weapons can contribute to a victory more than conventional weapons.

Keywords: biological war, epidemic, terrorism, plaque, smallpox, anthrax

\section{Wprowadzenie}

W środkach masowego przekazu często wspomina się o broni biologicznej i atakach bioterrorystycznych prezentując je jako sensację albo nowe zjawisko, które zostało zapoczątkowane na początku XXI wieku, jako pokłosie wydarzeń jakie miały miejsce po ataku na World Trade Center. Taka prezentacja faktów sprawia, że dla współczesnego odbiorcy, broń biologiczna utożsamiania jest tylko i wyłącznie z laseczką wąglika i atakami terrorystycznymi w Stanach Zjednoczonych w 2001 roku. Niniejszy artykuł stanowi przeciwwagę dla tego zjawiska i przedstawia pełną charakterystykę poszczególnych drobnoustrojów oraz przykłady ich użycia jako broni biologicznej od czasów starożytnych do początków XXI wieku. Niezależnie, czy użycie czynnika biologicznego następowało w czasach, gdy nie znano etiologii chorób zakaźnych czy współcześnie, w dobie rozwoju mikrobiologii, genetyki i biologii molekularnej, to jego wykorzystanie w trakcie prowadzenia działań o charakterze militarnym, może przyczynić się do odniesienia zwycięstwa bardziej, niż użycie broni o charakterze konwencjonalnym.

\section{Definicje broni biologicznej}

Broń biologiczna zaliczana jest do broni masowego rażenia. Organizacja Narodów Zjednoczonych (ONZ) definiuje ją jako atomowe ładunki wybuchowe skonstruowane w oparciu o substancje radioaktywne, chemiczne i biologiczne, a także wszelkie inne rodzaje broni o podobnej sile niszczącej jak bomba atomowa i powyższe rodzaje broni masowego rażenia (Michailuk, 2016) Według NATO bronią masowego rażenia nazywa się broń powodująca zniszczenia materii żywej i martwej na znacznych obszarach. Natomiast bronią biologiczną definiuje wszelkie materiały i środki techniczne zdolne do upowszechniania biologicznych środków trujących (czyli organizmów mikroskopijnych rozmiarów, które są przyczyną pogorszenia stanu zdrowia u ludzi, zwierząt i roślin oraz a także powodują u nich różne choroby (AAP-6, 2013). Encyklopedia PWN podaje, że broń biologiczną stanowią organizmy

Adres korespondencyjny: Marcin Weiner, Państwowa Szkoła Wyższa im. Papieża Jana Pawła II w Białej Podlaskiej, ul. Sidorska 95-97, 21-500 Biała Podlaska, e-mail: m.weiner@dydaktyka.pswbp.pl, tel.+48833449900

ORCID: Marcin Weiner: https://orcid.org/0000-0001-9288-0823, Karolina Tarasiuk: https://orcid.org/0000-0002-5926-5121 Copyright by: Państwowa Szkoła Wyższa im. Papieża Jana Pawła II w Białej Podlaskiej, Marcin Weiner, Karolina Tarasiuk 
takie jak pierwotniaki, wirusy, bakterie i grzyby, wszelkie niebezpieczne substancje, które one wydzielają, a także organizmy zdolne do przenoszenia masowych chorób zakaźnych wywoływanych przez czynniki patogenne wśród ludzi, oraz fauny i flory. (http://encyklopedia.pwn.pl/szukaj/bro\%C5\%84-biologiczna.html, dostęp: 30.04.2018)

Choroby zakaźne towarzyszą człowiekowi od zarania dziejów. Rozwojowi poszczególnych cywilizacji i poszczególnych państw towarzyszą gwałtowne upadki związane $\mathrm{z}$ występowaniem chorób zakaźnych takich jak dżuma, malaria, cholera lub wąglik. Pierwotnie za przyczynę ofiar śmiertelnych epidemii uważano siły wyższe i gniew bogów, z czasem jednak zaczęto dostrzegać pewne powiązania przyczynowo - skutkowe, które zostaną przedstawione w dalszej części opracowania, a które mogły przyczynić się do zwycięstwa bardziej, niż użycie oręża czy liczniejszej armii. Współczesne środki masowego przekazu co jakiś czas ujawniają „sensacyjne" informacje na temat nowych możliwości wykorzystania broni biologicznej jako narzędzia do prowadzenia działań wojennych bezpośrednio, lub jako element strategii i gry politycznej. Celem niniejszego opracowania jest zaprezentowanie wybranych czynników biologicznych i wykazanie, że ich użycie na polu walki nie jest niczym nowym, a historia zna wiele przypadków ich skutecznego użycia.

\section{Broń biologiczna w starożytności}

Pierwsze wzmianki na temat użycia broni biologicznej odnotowywano już w starożytności. Na terenie dzisiejszego Wietnamu wykorzystywano słupy punji w postaci zasadzek zapadniowych, natarte ludzkimi fekaliami. Scytyjscy łucznicy maczali strzały w rozkładających się ciałach i nieczystościach, a rzymscy żołnierze zanurzali miecze przed bitwą w padlinie i zwierzęcych odchodach (Croddy, Perez-Armendariz, Hart, 2003). Już w VI w. p. n. e. Asyryjczycy wykorzystywali sporysz (przetrwalnik pasożytniczego grzyba buławinki czerwonej) jako broni biologicznej do zatruwania studni, z których wrogowie czerpali wodę do celów spożywczych (Kalenik, 2003).

Chińczycy w II w. p. n. e. w starciach z nieprzyjacielem wykorzystywali kosze z pszczołami, którymi obrzucali przeciwnika (Kalenik, 2003). Istnieją również wzmianki o bojownikach Hannibala, którzy w czasie II Wojny Macedońskiej posłużyli się jadowitymi wężami, aby wywołać panikę na pokładzie i uniemożliwić prawidłowe prowadzenie floty króla Eumenesa (Croddy i in., 2003).

W czasie II wojny peloponeskiej, rozwinięte gospodarczo i militarnie Ateny doświadczyły najazdu Sparty. Sztuka oblężnicza tamtej epoki była na tyle prymitywna, że solidne mury miasta wydawały się dostateczną ochroną. Mury miasta okazały się jednak śmiertelną pułapką w momencie, gdy w porcie Pireus, będącym oknem Aten na świat, zaczęła się zaraza, opisana m.in. przez starożytnego historyka, Tukidydesa. Zakażenie spowodowała bakteria Salmonella typhi powodująca dur brzuszny (tyfus). Zdaniem naukowców wskutek tyfusu śmierć w Atenach poniósł co czwarty żołnierz, w tym najwybitniejszy w tym okresie Perykles. W wyniku zarazy Ateny przegrały konflikt ze Spartą w 404 r. p. n. e., i kilkadziesiąt lat po tym zdarzeniu na rozproszonych Hellenów najechał Filip II, król macedoński, który torował drogę swojemu synowi Aleksandrowi (Michalski, 2012).

Nieznane choroby bardzo często utrudniały bądź uniemożliwiały kampanie wojskowe oraz determinowały ogromne straty w zasobach wojskowych. Przykładem może tu być opis choroby zawarty w „Iliadzie”, która dotknęła greckich bojowników oblegających Troję - najpierw od niej padały zwierzęta, następnie ludzie (Anusz, 1995). Wielu pisarzy epoki antycznej (m. in. Hipokrates, Arystoteles, Avicenna) w swoich zapiskach odnotowywali zdarzenia mające związek z inwazjami pasożytniczymi i powiązanymi z nimi chorobami zakaźnymi wśród wojsk, które niejednokrotnie zmieniały bieg bitew i całych kampanii wojskowych. Przede wszystkim szkody czynione przez choroby zakaźne dotyczyły dużych formacji zbrojnych zorganizowanych na niewielkim obszarze, które pokonywały wiele kilometrów w dłuższym czasie (Michalski, 2012).

\section{Tularemia}

Tularemia jest ostrą bakteryjną chorobą zakaźną, której czynnikiem etiologicznym jest pleomorficzna, gram-ujemna pałeczka Francisella tularensis, występująca u ludzi i zwierząt. Typowym objawem choroby jest obrzęk zmienionych węzłów chłonnych, może również wystąpić posocznica. W naturalnych warunkach do zachorowania dochodzi na skutek ukąszeń człowieka przez owady przenoszące w swej ślinie bakterie. W przypadku potencjalnego ataku biologicznego, na skutek rozpylenia w powietrzu bakterii, występuje tzw. forma tyfoidalna. Zapalenie gardła, któremu często towarzyszy zapalenie płuc, może wystąpić aż u 80\% pacjentów (Dennis, 2001). W 2016 r. w krajach UE potwierdzono laboratoryjnie 1056 zachorowań u ludzi (współczynnik zapadalności 0,21/100 000 osób), co oznaczało niewielki spadek w odniesieniu do 2015 r. W tym samym czasie odnotowano 18 zakażeń w Polsce (EFSA, 2017).

W starożytności udanym przypadkiem ataku biologicznego z wykorzystaniem pałeczki Francisella tularensis była ekspansja Hetytów na Bliski Wschód. Z tego powodu tularemia do dziś nazywana jest chorobą hetycką. Pustoszyła ona tereny Bliskiego Wschodu pod koniec XIV w. p. n. e. Hetyci użyli zarażonych pałeczką zwierząt, które wysłali do obozu wroga, co doprowadziło do rozprzestrzenienia się choroby u nieprzyjaciela. Wskutek tych działań zachorował sam władca Arzawy - Uhha- 
zitis, nie mniej jednak ofiarami tej choroby padli także królowie Hetyccy - Suppilium I i Arnuwand II (Janeczek, Chrószcz, Ożóg, 2010).

Radzieckie badania dotyczące broni biologicznej zostały zainspirowane epidemią tyfusu po I wojnie światowej, która zaatakowała ok. 30 mln ludzi, z czego jego ofiarami się stało 3 mln Rosjan. Przed wybuchem II wojny światowej w tajnym ośrodku bakteriologicznym w Suzdalu badano możliwości wykorzystania wielu czynników zakaźnych, między innymi tularemii ale także dżumy, tyfusu i gorączki Q jako broni biologicznej (Croddy i in., 2003). Rozpoczęte wtedy badania przyczyniły się do wykorzystania tego drobnoustroju na froncie II wojny światowej, kiedy to radzieccy żołnierze w latach 1942 - 1943 zainfekowali bakteria tularemii niemieckich żołnierzy w ciągu trwania oblężenia Stalingradu, co poskutkowało licznymi zachorowaniami po obu walczących stronach na tę chorobę (Weiner, Kubajka, 2015).

Równocześnie z przystąpieniem USA do II wojny światowej, Amerykanie rozpoczęli program badań nad bronią bakteriologiczną. W tym celu zostały zbudowane dwa laboratoria - Camp Detrick i Camp Frederick - które prowadziły eksperymenty w warunkach poligonowych (Zieliński 2010). Początkowo badania dotyczyły tylko wąglika i bakterii z rodziny Brucella. W krótkim czasie program badań rozszerzono o inne biologiczne czynniki chorobotwórcze dla człowieka, przede wszystkim tularemii i dżumy, ale także chorobotwórczych dla zwierząt (księgosusz, ptasia grypa, pryszczyca) i upraw rolnych (zaraza ryżowa, rdza pszenicy, rdza ziemniaczana) (Croddy i in., 2003).

Po zakończeniu II wojny światowej, badania nad wykorzystaniem pałeczki tularemii w USA zostały zmniejszone do skali laboratoryjnej, wyłącznie na cele badawcze. Warto jednak zaznaczyć, że Stany Zjednoczone swój program badań broni o charakterze biologicznym rozszerzyły w okresie konfliktu koreańskiego. Kwestia przenoszenia na duże odległości patogenów chorobotwórczych wciąż nie była zamknięta, co nie zmienia faktu, że jak dotąd nikt nie posiadał śmiercionośnego, aktywnego, łatwego do upowszechnienia i niedrogiego czynnika wojny biologicznej. W 1951 r. Korea Pn. wystosowała oskarżenie w stronę Stanów Zjednoczonych, Korei Pd. i ich sojuszników jakoby wytwarzały broń bakteriologiczną do przypuszczenia ataku na nią. Donos Koreańczyków mówił o incydentach lotniczych wypuszczania nad liniami frontu owadów zarażonych różnymi czynnikami chorobotwórczymi w celu wywoływania chorób zakaźnych oraz oskarżał Stany Zjednoczone o planowanie i dokonywanie ludobójstwa na żołnierzach KAL (Koreańskiej Armii Ludowej), ChOL (Chińskich Ochotników Ludowych) oraz niekonfliktowych obywatelach Korei Pn. Oczywiście, Stany Zjednoczone w odpowiedzi na zarzuty przedstawione przez Koree Pn. wszystkiemu zaprzeczyły, a sama Korea Pn. i jej sojusznicy (Chiny i ZSRR) odmówiły przeprowadzenia śledz- twa przez Międzynarodowy Komitet Czerwonego Krzyża (Croddy i in., 2003).

W latach 60. ubiegłego wieku USA przeprowadziło jeszcze wiele eksperymentów z zakresu wykorzystania broni biologicznej. Do momentu przerwania badań nad bronią biologiczną pod koniec lat 60. Stany Zjednoczone miały na swoim wyposażeniu aż 7 typów standaryzowanej broni biologicznej. Do zabójczych środków biologicznych zaliczono m. in. bakterie wąglika i tularemii, a do czynników, które były przyczyną niezdolności do walki wpisano brucelozę, gorączkę Q i VEE. Uzbrojenie przeszło pewne modyfikacje, gdzie wykorzystywano zabójcze toksyny SEB oraz botulinę (Croddy i in., 2003).

\section{Dżuma}

Dżuma (Pestis) jest bakteryjną chorobą zakaźną człowieka. Czynnikiem etiologicznym dżumy jest niewytwarzająca zarodników bakteria Yersinia pestis. Dżuma występuje w kilku postaciach klinicznych: dymieniczej, posocznicowej (septycznej), oraz płucnej (pierwotnej i wtórnej) Bez leczenia postać dymienicza kończy się śmiercią w $50 \%$ przypadków W postaci płucnej (pestis pneumonica) występują objawy ciężkiego, wysiękowego zapalenia płuc, z krwiopluciem, dusznością i sinicą a śmiertelność sięga 100\% (Mwengee, 2006). Wg danych WHO w latach 2010-2015 odnotowano 3248 zachorowań I 584 przypadki śmiertelne (http://www.who.int/ en/news-room/fact-sheets/detail/plague).

Pierwsze wzmianki dotyczące masowych zachorowań na dżumę dotyczą starożytnego Rzymu. W II w. n. e. plany rzymskie dotyczyły rozszerzenia granic imperium o ziemie należące do germańskich ludów z terenów dzisiejszych Czech i Moraw, i utworzenie tam nowej prowincji - Markomanii. Jednakże w 165 r. n. e. legioniści zostali zaatakowani przez nieznaną chorobę - dżumę. Kasjusz Dion, rzymski historyk pochodzenia greckiego, zapisał, iż w samym centrum imperium w jeden dzień śmierć w wyniku choroby ponosiło ok. 2 tys. osób. Szacuje się, że ogólnie liczba osób zmarłych na zarazę wynosi co najmniej $5 \mathrm{mln}$ mieszkańców całego Imperium Rzymskiego; w tym dosięgła dwóch cesarzów: Lucjusza Werusa (169 r. n. e.) i Marka Aureliusza (180 r. n. e.). Osłabienie armii legionistów wskutek choroby, a nie siła ludów germańskich, zatrzymała ekspansję Rzymu na północ i udaremniła stworzenie nowej prowincji - Markomanii (Piotrowska, 2010).

Epidemie wśród żołnierzy odcisnęły także swoje piętno podczas wypraw krzyżowych. W pierwszej krucjacie (1089 r.) armia stacjonująca pod Antiochią w sile 300 tys. żołnierzy w ciągu 12 lat w wyniku chorób zmniejszyła swą liczebność o 94\%. Natomiast czwarta z kolei wyprawa krzyżowa pod przywództwem Baldwina z Flandrii nie dotarła do Jerozolimy z powodu szalejącej dżumy. Przez okres ponad dwóch tysięcy lat historia odnotowała aż 41 przypadków epidemii „czarnej śmierci”, która za- 
wleczona do Europy na początku przez Rzymian, a potem przez armie krzyżowców, zabijała mieszkańców wsi i miast (Michalski, 2012). Dżuma stanowiła broń biologiczną, której używały zwaśnione strony w swoich bitwach. Pierwszym przykładem wykorzystania jej w walce jest oblężenie krymskiego portu Kaffy przez wojska tatarskie w 1346 r. Opisy nie podają w jakim stopniu zaraza stała się przyczyną ostatecznego triumfu Tatarów. Otoczony murami port Kaffa, przepełniony handlarzami i kupcami z włoskiej Genui, zacięcie broniony przez mieszkańców, okrążony przez tatarów pozostawał długo niezdobyty. Tuż przed odwrotem, przywódca wojsk Janibeg rozkazał swojej armii, by katapultowali ciała zmarłych na dżumę żołnierzy za mury miasta. Obrońcy Kaffy przerzucili tych samych nieboszczyków z powrotem na stronę tatarską. Nikt z historyków nie podaje wartości dotyczących strat po obu stronach z tego tytułu. Skutkiem epidemii „czarnej śmierci” było czasowe zachwianie zdolności obronnych mieszkańców Kaffy, wskutek czego miasto portowe niedługo potem zostało zdobyte przez Tatarów. Uciekinierzy z miasta kierowali swoje statki (na których podróżowały także szczury i pchły zarażone dżumą) do innych portów w basenie Morza Śródziemnego: Konstantynopola, Marsylii czy Wenecji, a także do odleglejszych portów europejskich. Według większości historyków był to początek wielkiej pandemii dżumy, która szalała w Europie w XIV wieku (Kalenik, 2003). Prawdopodobnie „czarna śmierć” panująca w Europie opóźniła o mniej więcej 100 lat nadejście nowej epoki - renesansu. Ofiarą dżumy mogło paść nawet połowa, a nawet więcej (ok. 60\%) Europejczyków zamieszkujących ówcześnie kontynent. Bezrobocie oraz niezdolność władz do rządzenia były przyczyną załamania się systemu feudalnego oraz modernizacji i reformy starych form organizacji społeczeństwa. Warto także dodać, że lęk przed możliwością powrotu dżumy stał się przyczyną zamykania łaźni W miastach i popularyzacje „kultu brudu” (Piotrowska, 2009). W średniowieczu patogen dżumy wykorzystano jeszcze w 1422 r. w batalii pod Carolstein, podczas której ciała zmarłych żołnierzy katapultowano na oddziały wojsk wroga (Kalenik, 2003).

W 1710 r., w czasie wojny rosyjsko-szwedzkiej, został wykorzystany patogen dżumy, analogicznie jak miało to miejsce $w$ średniowieczu podczas bitwy pod Carolstein. Rosjanie, nie mogąc zdobyć skutecznie bronionego przez Szwedów miasta, przerzucili na teren Revalu (współcześnie Tallin) nieboszczyków zmarłych na dżumę, doprowadzajac w konsekwencji do upadku miasta (Kalenik, 2003).

Na początku lat 40. XX wieku, Japonia zrzuciła nad obszarem Mandżurii i pobliskimi regionami bomby ceramiczne, w których znajdowały się pchły zainfekowane bakterią dżumy. Siła eksplozji rozrzuciła ziarno, zwabiając szczury, na które miały przedostawać się zarażone pchły. Te z kolei przenosiły chorobę dalej na społeczeństwo. Wielokrotnie (aż 11 razy!) chińskie miasta były atakowane przez Japonię róż- nego rodzaju czynnikami biologicznymi skażającymi żywność i wodę przy pomocy agrotechnicznych rozpylaczy. Mimo wielu japońskich prób bioataku, większość kończyła się porażkami: w jednym z przypadków ataku z użyciem czynników biologicznych, w którym wykorzystano bakterie cholery do skażenia rzeki, zachorowało 10 tys. żołnierzy, z czego prawie 2 tys. zmarło (Croddy i in., 2003).

Klęska Japonii w II wojnie światowej pokrzyżowała plany wykorzystania broni bakteriologicznej przeciwko aliantom (Bińczycka-Anholcer, Imiołek 2011). Po kapitulacji, Japońscy dowódcy nakazali rozwiązanie jednostek 731 i 710 znajdujących się na obszarze Mandżurii (która w późniejszym czasie została zajęta przez Związek Radziecki) oraz zniszczenie wszelkich dokumentów związanych z prowadzonymi badaniami nad bronią bakteriologiczną i zburzenia laboratoriów badawczych. W 1946 r., na skutek porozumienia zawartego między Japonią i Stanami Zjednoczonymi, że w zamian za dostęp do utajnionych danych związanych z bronią bakteriologiczną, zostały odwołane śledztwa i cofnięte wszelkie oskarżenia wobec zbrodniarzy wojennych z Japonii (Kalenik, 2003).

Program badań w ZSRR nad pałeczkami dżumy (ale także wąglika) realizowały nie tylko zakłady w Swierdłowsku, ale także w Stepnogorsku na obszarze Kazachstanu. Aby zataić fakt badań nad bronią biologiczną postarano się o zakamuflowanie zewnętrznych instalacji, które mogłyby być kojarzone z produkcją broni bakteriologicznej (np. w Obleńsku zakład do badań nad bronią biologiczną został zaprojektowany w taki sposób, aby z zewnątrz wyglądał jak szpital, a w Stepnogorsku uży to nowoczesnych technologii w celu uzyskania efektu niewykrywalności obiektu na zdjęciach satelitarnych (Croddy i in., 2003). Rosyjscy biolodzy prawdopodobnie prowadzili badania w zakresie użycia patogenów chorobotwórczych jako broni co najmniej do lat 80. XX wieku. Ken Alibek, lekarz wojskowy, który był zatrudniony jako kierownik zakładu w Stepnogorsku i „Biopreparatu”, twierdzi, że działalność badawcza nad bojowymi środkami biologicznymi nie została przerwana pomimo wydanego zakazu Jelcyna w tej dziedzinie, i może trwać po dzień dzisiejszy (Croddy i in., 2003).

\section{Wąglik}

Wąglik (łac. anthrax) jest zakaźną i zaraźliwą chorobą wywoływaną przez Gram-dodatnią bakterię - laseczkę wąglika (Bacillus anthracis). Wąglik występuje najczęściej u bydła, koni, owiec i kóz, natomiast ptaki są niewrażliwe na naturalne zakażenie (WHO, 2008)). Każdego roku na wąglik zapada około 2000 osób (GIDEON, 2016). Postać skórna wąglika dotyczy 95\% przypadków, które nieleczone, w $24 \%$ kończą się śmiercią. W pozostałych 5\%, w postaci jelitowej i płucnej, pomimo zastosowanego leczenia, śmiertelność sięga odpowiednio 75 i 85\% (Inglesby, 1999). 
Pierwsze wzmianki na temat wąglika sięgają XII wieku i odnoszą się do greckiego słowa anthrakis, to znaczy węgiel, związanych z czarnymi zmianami skórnymi występującymi na ciele zarażonych osób i zostały opisane w „Bartholomaeus Anglicus' De Proprietatibus Rerum”.

Trzy lata przed wybuchem I wojny światowej, dr Anton Dilger, obywatel Stanów Zjednoczonych o niemieckich korzeniach, zatrudniony w charakterze chirurga w John's Hopkins University w Baltimore, na swojej prywatnej posesji namnożył szczepy wąglika i nosacizny, które dostał od niemieckiego rządu i przekazał sympatyzującym z Niemcami robotnikom stoczni Baltimore, których zadaniem było zainfekowanie ok. 4 tys. koni, mułów i bydła przeznaczonych do transportu na kontynent europejski jako pomoc dla Aliantów (Kalenik, 2003). Nie mniej jednak sami Niemcy też były ofiarami sabotażowych ataków biologicznych, m. in. niemiecki wywiad odkrył, że Francuzi przebywający na terytorium Szwajcarii rozprowadzają wśród koni, przeznaczonych do transportu na obszar Niemiec, bakterię Burkholderia mallei (Croddy i in., 2003). W roku wybuchu I wojny światowej lotnicy niemieccy zrzucili nad obszarem ziem Rumunii owoce, zabawki dla dzieci oraz słodycze zakażone wąglikiem i nosacizną Dopiero w okresie międzywojennym, w 1924 r. Międzynarodowa Komisja obwiniła Niemcy o stosowanie czynników biologicznych w Italii, Rosji i Rumunii; jednak nie udowodniono postawionych zarzutów (Kalenik, 2003).

II wojna światowa zdeterminowała Japończyków do wzmożonych badań nad bronią o charakterze bakteriologicznym $w$ rejonie Mandżurii. Zorganizowano w tym celu dwie jednostki 731 i 710, które miały zajmować się rozwojem broni bakteriologicznej oraz posługiwać się zdobytą teorią w praktyce. Po 1930 r. eksperymentowano na ludności pozostającej na terenach zajętych przez wroga oraz na więźniach wojennych. W wyniku prowadzonych doświadczeń miliony ludzi zmarło. Ciężko jest oszacować przybliżoną liczbę cywilów, którzy stali się ofiarami prób poligonowych i doświadczalnych eksperymentów biologicznych japońskich badaczy. Wojna pozwoliła na nagromadzenie blisko pół tony bakterii Bacillus anthracis, możliwych do zastosowania dzięki odpowiednio zbudowanej bombie odłamkowej (Bińczycka-Anholcer, Imiołek, 2011).

W czasie II wojny światowej Wielka Brytania prowadziła badania nad możliwością wykorzystania patogenów chorobotwórczych jako broni, mające na celu zabezpieczenie się przed ewentualnym atakiem Niemiec przy wykorzystaniu broni biologicznej. Warto dodać, że III Rzesza też badała bakterie wąglika w charakterze użycia ich jako broni biologicznej w miejscowości Pokrzywno k/Poznania. (Zieliński, 2010). W latach czterdziestych ubiegłego wieku, na niezamieszkałej wyspie Griunard niedaleko Szkocji, zrzucano bomby z wąglikiem. Wskutek tego doświadczenia zginęły na wyspie wszystkie zwierzęta, a aktywność przetrwalników Bacillus anthracis obserwowano jeszcze pół wieku po przeprowadzonym eksperymencie i dezynfekcji wyspy ciekłym formaldehydem po 1980 r. (Bińczycka-Anholcer, Imiołek, 2011).

W okresie II wojny światowej listy zawierające wąglik w swoich działaniach próbowała wykorzystywać Armia Krajowa, jednak bez większego powodzenia (Zieliński, 2010).

Wiosną 1943 r. w londyńskiej fabryce mydła zostało wytworzonych 5 mln porcji paszy, w które wstrzyknięto zawiesinę $\mathrm{z}$ wąglikiem. Było to celowe działanie odwetowe w przypadku niemieckiej agresji biologicznej na Wielką Brytanię, które przewidywało rozrzucenia zainfekowanej paszy po łąkach i polach nieprzyjaciela. Meritum planu stanowiło zainfekowanie wąglikiem bydła mięsnego (Croddy i in., 2003).

Po II wojnie światowej sowieccy badacze wykorzystali wiedzę uwięzionych mikrobiologów niemieckich jak również informacje zdobyte dzięki zajęciu Mandżurii. W Zagorsku k/Moskwy wybudowano ośrodek badawczy broni bakteriologicznej. Wykonywano tam projekty związane z różnymi drobnoustrojami (Chomiczewski, 2003). Lata siedemdziesiąte XX wieku w Związku Radzieckim naznaczone były konspiracyjnymi badaniami nad bronią biologiczną w ośrodku „Wszechzwiązkowym Naukowo-Produkcyjnym Zjednoczenia Biopreparat”. Program „Biopreparat” obejmował swoim zakresem produkcję biopestycydów (które były przykrywką dla innych zamiarów) nawozów i szczepionek. Co ważniejsze była to legalna działalność zarówno handlowa jak i wojskowa. Wszelkie domysły wskazują na fakt, iż już w 1978 r. ZSRR wprowadziło do swojego wachlarza zbrojeniowego bakterią dżumy (Croddy i in., 2003). Największym kompleksem był ośrodek nr 19, gdzie ulepszano sowieckie zasoby zbrojeniowe broni biologicznej o sproszkowane bakterie wąglika. Wskutek niedopatrzenia jednego z techników doszło w kompleksie do awarii, w której ulotnił się pył z wąglikiem (Chomiczewski, 2003). Skażenie spowodowało śmierć zarówno pracowników nocnej zmiany, jak również robotników pobliskiego zakładu ceramicznego. Incydent ten, jest największym znanym do tej pory sytuacją epidemii wąglika postaci płucnej (Dakowski, 2017).

W 1997 r. organizacja terrorystyczna Counter Holocaust Lobbyist of Hitler potajemnie dostarczyła do budynków użyteczności publicznej podpisane płytki z wąglikiem i dżumą. Wkrótce po tym incydencie, sytuacja ta okazała się fałszywym alarmem - wskutek którego poniesione zostały ogromne koszty związane z neutralizacją zagrożenia biologicznego (Kalenik, 2003). Pod koniec lat 90. alarm wzniecono w aborcyjnych szpitalach, gdzie miały dotrzeć listy z przetrwalnikami wąglika. Po zamachu na WTC w 2001 przy użyciu listów z wąglikiem próbowano wywołać epidemię tej choroby. Skażone listy trafiły do siedzib środków masowego przekazu (stacji telewizyjnych, New Jersey Post) i firmy American Media (na półwy- 
spie florydzkim). Kolejne listy z przetrwalnikami wąglika mieli otrzymać politycy z Partii Demokratycznej. Biologiczny atak terrorystyczny, który nastąpił niespełna kilka dni po najtragiczniejszym $\mathrm{w}$ dziejach Stanów Zjednoczonych zamachu na WTC, uśmiercił 5 osób (Kęciek, 2010).

\section{Ospa}

Bardzo groźną zakaźną chorobą wirusową o ostrym przebiegu i wysokiej śmiertelności jest ospa prawdziwa (Variola vera - czarna ospa). Historia wskazuje, że jej pierwszą ofiarą śmiertelną był faraon Ramzes V (1160 r. p. n. e.), natomiast pierwszą epidemię ospy prawdziwej datuje się na lata wojny peloponeskiej pomiędzy Ateńczykami i Spartanami (431 - 404 r. p. n. e.) (Finkel, 2007). Setki lat później, konkwistadorzy z Hiszpanii odnosili zwycięstwa tylko dlatego, iż byli w posiadaniu lepszego uzbrojenia (armat i muszkietów), jednakże to broń o charakterze biologicznym, którą całkiem nieświadomie przenieśli ze sobą, stała się przyczyną większych szkód i strat, niż oręż. Na początku XVI w., Herman Cortes dopłynął do ówczesnych ziem Azteków. Był widziany przez tubylców jako bóg, jednakże z biegiem czasu te postrzeganie zmieniło się na bardziej negatywne, zostały wzniecone rebelie i hiszpańscy kolonizatorzy byli zmuszeni do opuszczenia azteckiego terytorium. Podczas walk zmarł na ospę prawdziwa jeden z żołnierzy. Aztekowie przeszukując zwłoki poległych nieświadomie zarażeni zostali wirusem ospy. Choroba powoli, ale systematycznie wyniszczała aztecka społeczność - począwszy od zwykłych robotników, poprzez wojskowe oddziały, aż po samego imperatora. Brak możliwości grzebania dużej liczby ofiar spowodowała, że zawalano domy, w których spoczywali umarli, aby stały się ich grobem. Konkwistadorzy dotarli aż do Tenochtitlan, gdzie Cortes powiedział, że w tym miejscu ospa zabrała więcej Azteków niż hiszpańskie armaty. Ospa prawdziwa szybko się upowszechniła po miejscach zamieszkania Inków, zabijając w ciągu kilku miesięcy imperatora, jego dziedzica oraz ważnych wojskowych dowódców w imperium. Wkrótce potem imperium Inków zostało zaatakowane przez Francisca Pizarro (Michalski, 2012). Zdanie są podzielone, czy mieszkańcy Starego Kontynentu uciekali się do wykorzystania broni biologicznej w podbijaniu ziem Ameryki przed 1700 r., czy naturalne rozprzestrzenianie się chorób stawało się przyczyną śmierci wielu tubylców, którzy nie posiadali odporności na dolegliwości Europejczyków, co w znacznej mierze ułatwiło kolonizację Nowego Kontynentu. Prawdopodobnie, od czasów pierwszego kontaktu miejscowych z Europejczykami na początku XVI w., wskutek przewiezionych przez ocean różnych epidemii i chorób, zmarło ok. 95\% rodowitych mieszkańców Ameryki (Croddy i in., 2003).

Istnieją zapisy o wykorzystaniu patogenu ospy prawdziwej w działaniach wojennych Francji prze- ciw Indianom w latach 1754 - 1760 przez pułkownika Henry'ego Bouqueta i gen. Jeffrey'a Amhersta, poprzez podarowanie tubylcom, lojalnym wobec Francuzów, pledów i odzieży skażonych tym wirusem. Chociaż nieuczciwe działania miały znikome skutki, stały sie jednak kamieniem milowym wojen biologicznych (Croddy i in., 2003). Piętnaście lat po tym incydencie wybuchła rewolucja amerykańska, w której dowódca Benedict Arnold poprowadził swoje oddziały w celu podbicia ziem kanadyjskich. Próba zdobycia Quebecu zakończyła się fiaskiem wymuszając odwrót armii Arnolda. Wśród szeregów szybko upowszechniła się informacja, że Brytyjczycy roznosili między nimi wirusa ospy prawdziwej dzięki ludziom utrzymującym kontakty z siłami lądowymi. Poglądy potwierdził później sam Thomas Jefferson oskarżając przywódcę Brytyjczyków w Quebecu o działania mające na celu zainfekowanie wojsk amerykańskich (Croddy i in., 2003). W okresie Wojny Secesyjnej, angielskiemu generałowi Charlesowi Cornwallisowi proponowano rozesłanie po plantacjach popierających bunt, 700 ciemnoskórych mężczyzn zainfekowanych ospą. Skutki tego działania są jednak nieznane (Croddy i in., 2003).

Z przytoczonych powyżej przykładów wynika niezbicie, że drobnoustroje uznawane za potencjalną broń biologiczną oraz mogące zaleźć zastosowanie w ataku bioterrorystycznym znane są ludzkości od tysiącleci i występują naturalnie w przyrodzie, choć naturalna zachorowalność na nie jest stosunkowo niska. Doniesienia prasowe poświęcają mało uwagi drobnoustrojom, mniej typowym dla naszej strefy klimatycznej, a które przyczyniły się w przeszłości, ale także oddziałują obecnie na globalną problematykę zdrowotną. Należy przypuszczać, że $\mathrm{z}$ czasem, albo z przyczyn naturalnych takich jak dostosowywanie się patogenów do nowych warunków środowiska, ale także na skutek niekontrolowanych manipulacji materiałem genetycznym patogenów, dojdzie do przełamania naturalnych barier środowiskowych (góry, morza, temperatura otoczenia, żywiciele pośredni) i ich rozprzestrzenienia na całym świecie. Przykładem takiej choroby jest malaria.

\section{Malaria}

Malaria to ostra lub przewlekła choroba pasożytnicza wywoływana przez pierwotniaka z rodzaju Plasmodium. Wektorem malarii przenoszącym ja między osobami chorymi i zdrowymi sa samice komarów z rodzaju Anopheles (Mendis, 2001). Malaria jest najczęstszą na świecie chorobą zakaźną, na którą co roku zapada ponad $220 \mathrm{mln}$ osób. Szacuje się, że w roku 2016, zachorowało na malarię 216 milionów osób, to jest o 5 milionów osób więcej w porównaniu z rokiem 2015 (WHO, 2017). W Polsce malaria praktycznie nie występuje a jeśli, to ma charakter choroby typowo tropikalnej zawleczonej przez osoby przebywające $\mathrm{w}$ krajach, gdzie możliwe 
jest naturalne rozprzestrzenianie tej choroby, na skutek ukąszenia przez podatnego na pierwotniaka komara. W chwili obecnej żaden $\mathrm{z}$ występujących w Polsce gatunków komarów nie jest wrażliwy na infekcję wywołaną przez pierwotniaka z rodzaju Plasmodium.

Pierwsze pisane wzmianki dotyczące objawów chorobowych odpowiadających współczesnej malarii pochodzą ze starożytnego Rzymu (z łaciny mal'aria znaczy „złe powietrze”), jednak współczesne badania naukowe oparte na sekwencjonowaniu materiału genetycznego w wykopaliskach sprzed 10-15 tysięcy lat wskazują, że choroba ta towarzyszy człowiekowi od początku istnienia cywilizacji i początek wzięła od małp człekokształtnych. Twierdzono ówcześnie, że jej przyczyną były opary z bagien. Wskutek choroby śmierć poniosło 4 papieży i bardzo prawdopodobne, że jej ofiarą padł także sam Dante (Finkel, 2007). Malaria ma określone granice występowania - istnieje na obszarze izoterm o wartościach $16-20^{\circ} \mathrm{C}$ na północy oraz izotermą $20^{\circ} \mathrm{C}$ na południu, $\mathrm{z}$ taką uwagą, iż na terenach górzystych jest obecna nawet do $1500 \mathrm{~m} \mathrm{n}$. p. m. W 701 r. p. n. e. Jerozolima była oblegana przez Asyryjczyków, ale do bezpośredniego ataku nigdy nie doszło, ponieważ w obozie napastników na malarię zmarło aż 185 tys. żołnierzy, co znacznie osłabiło asyryjskie siły. W 1938 r. na obszarze dawnych bitew Judejczyków z Asyrią, archeolog Starkey odkrył grobowiec, w którym złożono ponad 1500 szkieletów. Dwadzieścia jeden lat przed tym odkryciem, na tych samych terenach Anglicy walczący z Turkami zdobyli Jerozolimę, okopując się w miejscu dawnego obozu asyryjskiego króla Sanheriba 375 m n. p. m. Kilkaset angielskich żołnierzy odesłano na spoczynek do obozu leżącego na wysokości Jerozolimy 790 $\mathrm{m}$ n. p. $\mathrm{m}$. W niedługo potem znaleziono $\mathrm{w}$ namiotach większą połowę bojowników martwych z powodu malarii. Ofiary były już wcześniej zarażone, lecz dopiero gwałtowna zmiana temperatury (z gorącej doliny Jordanu na chłód jerozolimskich wzniesień) spowodował uaktywnienie się zarodźców malarii w organizmach żołnierzy (Michalski, 2012). Do najbardziej znanych ofiar tej choroby zalicza się Aleksandra Macedońskiego, który zmarł w wieku 33 lat w 323 r. p. n. e., oraz króla Gotów i zdobywce Rzymu - Alaryka (IV w. n. e.). Malaria wstrzymała też niejedną wyprawę zbrojną oraz liczne napaści, których przykładem może być najazd Hunów na Rzym pod przywództwem Atylli (w 452 r. n. e.), oblężenie Rzymu przez armię Belizariusza (w 536 r. n. e.) czy też nieudana akcja zbrojna Fryderyka I Barbarossy na wieczne miasto (Blech, 2010).

Szacuje się, że straty wojsk brytyjskich będące skutkiem zachorowania na malarie w okresie podbojów napoleońskich w latach 1793 - 1815 sięgały ponad 200 tys. żołnierzy, a prawie pięćdziesiąt lat później (w czasie wojny secesyjnej 1861-1865) odnotowano ponad 1,3 mln incydentów gorączkowych malarii, z czego aż 10 tys. było przyczyną zgonów (Naruszewicz-Lesiuk, Magdzik, 2000).
Malaria na froncie macedońskim podczas I wojny światowej powstrzymała na około 36 miesięcy oddziały Francuzów, Anglików i Niemców, zmuszajac do leczenia szpitalnego ponad $80 \%$ żołnierzy (Blech, 2000). Natomiast w czasie II wojny światowej w obszarze Oceanu Spokojnego wskutek zachorowania na malarię, śmierć poniosło więcej ludzi niż w wyniku prowadzonych tam bitew. Zdaniem niektórych badaczy 50\% istnień ludzkich, jacy kiedykolwiek żyli, umarło na tę chorobę (Finkel, 2007).

\section{Konwencje przeciwko broni biologicznej}

Protokół Genewski z 1925 roku był pierwszym dokumentem o randze międzynarodowej, który w swoich zapisach odniósł się do zakazu wykorzystania na wojnie gazów duszących, trujących lub podobnych oraz środków bakteriologicznych. Współcześnie, jest on zwyczajowym prawem o charakterze międzynarodowym - w myśl, którego wszystkie państwa są zobowiązane do respektowania jego zapisów. Nie mniej jednak Protokół odnosił się tylko do czasu wojny w zakresie użycia broni biologicznej, dlatego też gromadzenie, wytwarzanie i wszelkie badania nad nią były dopuszczalne. Kiedy Protokół Genewski nie sprawdził się w praktyce i potrzebował solidnych umocnień w postaci regulacji prawnych podjęto działania, wskutek których w 1972 roku uchwalona została Konwencja o zakazie prowadzenia badań, produkcji i gromadzenia zapasów broni bakteriologicznej i toksycznej oraz o ich zniszczeniu (ang. BWC lub BTWC). Porozumienie zakazywało obligatoryjnie wszystkim państwom realizację badań z zakresu broni biologicznej, oraz jej produkcji i magazynowania, a wszelkie zapasy tego rodzaju broni należało zniszczyć lub zmodernizować dla celów pokojowych. Jednocześnie, Konwencja nakreśliła definicję broni biologicznej, opisując ją jako wszystkie środki i substancje o charakterze mikrobiologicznym z przeznaczeniem niepokojowym, która zbyt ogólnie odnosiła się do tej problematyki, co w konsekwencji przyniosło spore trudności w klasyfikacji czynników patogennych mających zastosowanie w broni biologicznej. Generalnie, państwa mogły dalej wytwarzać i gromadzić środki biologiczne w celach wyłącznie pokojowych, a nawet wykorzystać je jako środek obronny w momencie wystąpienia zagrożenia militarnego. Nie mniej jednak Konwencja z 1972 roku nie przewidywała konkretnego mechanizmu kontroli przestrzegania jej zapisów, co z kolei zapoczątkowało działania w zakresie opracowania protokołu regulacji przestrzegania przepisów BWC. Projekt protokołu został odrzucony (przy stanowczym sprzeciwie USA), czego następstwem było stworzenie przez Radę Bezpieczeństwa ONZ całościowego systemu zapobiegania proliferacji broni bakteriologicznej. Wskutek działań Rady Bezpieczeństwa uchwalono Rezolucje 1540/2004, która poruszała kwestie zagrożeń o charakterze terrorystycznym oraz niebezpieczeństw związanych $\mathrm{z}$ wytwarzaniem, dystry- 
bucją, badaniami, używaniem i przemieszczaniem broni biologicznej. Takie działania zostały zakwalifikowane jako zagrożenia bezpieczeństwa i pokoju międzynarodowego. Oparta na Karcie Narodów Zjednoczonych Rezolucja Rady Bezpieczeństwa ONZ w zakresie przeciwdziałania upowszechnianiu broni masowego rażenia stworzyła nowatorski system kontroli jej rozprzestrzeniania.

$\mathrm{Na}$ polskim gruncie w odniesieniu do przeciwdziałania zagrożeniom o charakterze biologicznym istotnym elementem jest zapobieganie tego rodzaju niebezpieczeństw. Wśród skutecznych działań prewencyjnych należy wymienić:

- weryfikację zamiarów wykorzystania broni bakteriologicznej,

- posiadanie prostej i sprawnie działającej sieci nadzoru epidemiologicznego i specjalistycznych laboratoriów o charakterze mikrobiologicznym,

- odpowiednio wyszkolony personel medyczny zdolny do efektywnego działania w myśl wcześniej ustalonych procedur w warunkach presji czasu,

- dysponowanie specjalistycznym zapleczem szpitalnym,

- posiadanie systemów wykrywania i identyfikacji biologicznych czynników zagrożenia (głównie skuteczny monitoring epidemiologiczny zdolny do realizacji dokładnej i szybkiej analizy danych, a także dynamicznej wymiany informacji),

- stworzenie systemu granicznych stacji sanitarno-epidemiologicznych współpracujących ze Strażą Graniczną w zakresie monitoringu, wykrywania i kontroli prawdopodobnych niebezpieczeństw na gruncie biologicznym, a funkcjonujących pod pieczą Państwowej Inspekcji Sanitarnej,

- szkolenia i kursy personelu w obszarze nowatorskich sposobów lokalizowania czynników biologicznych,

- opracowania procedur postępowania i współdziałania różnych jednostek mundurowych na wypadek wystąpienia zagrożenia biologicznego,

- edukacja i uświadamianie władz państwowych o wadze możliwości wystąpienia potencjalnego niebezpieczeństwa na tle bioterrorystycznym.

Generalnie, polskie prawo jest bardzo ubogie jeżeli chodzi o kwestie regulacji zwalczania i nakładania kar w odniesieniu do terroryzmu, czy bioter- roryzmu. W głównej mierze spowodowane jest to faktem, iż Polska nie należy do krajów o wysokim prawdopodobieństwie wystapienia zamachu o charakterze terrorystycznym (z wyszczególnieniem bioataków). Kodeks karny przedstawia ogólnikowe ramy funkcjonowania sankcji w obszarze terroryzmu, mianując je przestępstwami związanymi z bezpieczeństwem powszechnym. Akcentuje także zakaz używania środków masowej zagłady.

\section{Podsumowanie}

Dzieje wojen biologicznych nie kończą się na historycznych zaszłościach. U progu XXI wieku do dnia dzisiejszego toczone są w postaci ataków bioterrorystycznych. Jesienią 1978 r. został przeprowadzony w Londynie skuteczny zamach na opozycjonistę Georgia Markowa przy pomocy cienkiej igły zanurzonej w rycynie ukrytej na końcu parasola. W podobny sposób miał zginąć bułgarski dysydent Kostow, jednakże zamach się nie udał. Sześć lat później „Rajneesh Puram” w Oregonie zatruło bakteriami duru brzusznego bary sałatkowe, aby przejąć władze w amerykańskim stanie. Na początku lat 90. XX wieku sekta Najwyższa Prawda rozpyliła w centrum Tokio przy japońskim parlamencie truciznę botulinową. Miała być to zemsta za nieudane wybory na stanowiska w japońskim rządzie, w których wcześniej startowali z ramienia swej partii o tej samej nazwie. W 1993 r. w identyczny sposób terroryści z sekty próbowali zakłócić ceremonię zaślubin pary królewskiej (Kalenik, 2003). Próba ataku bioterrorystycznego na japońskiego księcia i jego współmałżonkę była nieudana (Kizerwetter-Swida, Binek, 2010). Dwa lata później rozprzestrzenili w metrze sarin (gaz paraliżujący układ nerwowy) doprowadzając do śmierci 12 osób. Ofiarami ataku stało się ponad 5 tys. osób znajdujących się $\mathrm{w}$ tym czasie $\mathrm{w}$ miejscu zamachu. Broń biologiczna jest jednym z najważniejszych zagrożeń dla ludności cywilnej ale także dla sił zbrojnych. Użycie drobnoustrojów w celu umyślnego spowodowania chorób infekcyjnych ludzi, zwierząt i roślin jest powszechnie bardziej potępiane niż broń chemiczna. 0 ile działania profilaktyczno-prewencyjne wielu organizacji międzynarodowych dają możliwość opanowania pojawiających się co jakiś czas epidemii, tak gwałtowny rozwój biotechnologii i inżynierii genetycznej wraz z początkiem XXI budzi obawy ze względu na możliwość celowego spowodowania rozprzestrzeniania się chorób i utraty nad nimi jakiejkolwiek kontroli.

\section{Literatura:}

1. AAP-6 (2013), Słownik terminów i definicji NATO zawierający wojskowe terminy i ich definicje stosowane w NATO.

2. Anthrax: Global Status. GIDEON Informatics Inc. (2016).

3. Anusz, Z. (1995). Zapobieganie i zwalczanie zawodowych chorób odzwierzęcych, Olsztyn: Wyd. ART.

4. Bińczycka-Anholcer, M., Imiołek, A. (2011). Bioterroryzm jako jedna z form współczesnego terroryzmu. Hygeia Public Health, 3, 326-333. 
5. Blech, J. (2010). Pasożyty - Przyjaciele i wrogowie. Warszawa: OW „Interspar”.

6. Bohun, T. (2010). Królestwo Polskie kontra Imperium Rosyjskie. Mówiq Wieki, 11/10(610), 29-31.

7. Chomiczewski, K. (2003). Patogeny zwierzęce jako broń biologiczna. Przegląd Epidemiologiczny, 57, 35561.

8. Croddy, E., Perez-Armendariz, C., Hart, J. (2003). Broń chemiczna i biologiczna. Raport dla obywatela, Warszawa: Wydawnictwo Naukowo-Techniczne.

9. Dakowski, M., O Swierdłowsku - zatajonym bio-Czarnobylu. Pobrane z: http://dakowski.pl/index. php?option=com_content\&task=view\&id=5405\&Itemid $=47$

10. Dennis, D.T., Inglesby, T.V., Henderson, D.A., i in. (2001). Tularemia as a Biological Weapon. JAMA, 285, 2763-2773. https://doi.org/10.1001/jama.285.21.2763

11. EFSA (European Food Safety Authority) and ECDC (European Centre for Disease Prevention and Control) (2017). The European Union summary report on trends and sources of zoonoses, zoonotic agents and food-borne outbreaks in 2016. EFSA J., 15, 5077. https://doi.org/10.2903/j.efsa.2017.5077

12. Encyklopedia Multimedialna PWN, hasło: „broń biologiczna”. Pobrano z: http://encyklopedia.pwn.pl/ szukaj/bro\%C5\%84-biologiczna.html

13. Finkel, M. (2007). Chaos we krwi. Malaria. National Geographic Polska, 7(94), 28-63.

14. http://www.who.int/en/news-room/fact-sheets/detail/plague

15. Inglesby, T.V., Henderson, D.A., Bartlett, J.G., Ascher, M.S., Eitzen, E., Friedlander, A.M. (1999). Anthrax as a biological weapon: Medical and public health managment. JAMA, 281, 1735-1737. https://doi.org/10.1001/jama.281.18.1735

16. Janeczek, M., Chrószcz, A., Ożóg, T. (2010). Próby stosowania broni biologicznej i chemicznej w starożytności oraz epidemie i ich wpływ na dzieje. Życie Weterynaryjne, 85(3), 230-233.

17. Kalenik, J. M. (2003). Bioterroryzm - zagrożenie XXI wieku. Koszalin: Centralny Ośrodek Szkolenia Straży Granicznej.

18. Kęciek, K. Kto wysyłał waglika? Pobrane z: http://www.przeglad-tygodnik.pl/pl/artykul/kto-wysylal -waglika.

19. Kizerwetter-Świda, M., Binek, M. (2010). Zatrucie jadem kiełbasianym - problem wciąż aktualny. Postępy Mikrobiologii, 49, 75-85.

20. Kocięcka, W. (1996) Włosień kręty i włośnica. Wrocław: Cornetis.

21. Lach, J., Sulgostowska, T., Bzdęga, J. (2006). Inwazje pasożytnicze u żołnierzy armii europejskich stacjonujących w klimacie tropikalnym lub subtropikalnym w II połowie XX wieku. Prob. Hig. Epidemiol., 87(2), 92 -96.

22. Mendis, K., Sina, B., Marchesini, P., Carter, R. (2001) The neglected burden of Plasmodium vivax malaria. Am J Trop Med Hyg., 64(1-2 Suppl), 97-106.

23. Michailuk, B. (2016). Broń biologiczna i bioterroryzm, Zeszyty Naukowe AON, 1(102), 17-27.

24. Michalski, M. M., Epidemie jako przyczyny porażek militarnych oraz poważnych strat osobowych i materialnych. Pobrane z: http://wet.uwm.edu.pl/wiedza-ogolna/plik/epidemie-jako-przyczyny-porazek-militarnych-oraz-powaznych-strat-osobowych-i-materialnych/135/file/

25. Mwengee, W., Butler, T., Mgema, S., Mhina, G., Almasi, Y., Bradley, Ch., Formanik, J.B., Rochester, C.G. (2006). Treatment of Plague with Gentamicin or Doxycycline in a Randomized Clinical Trial in Tanzania. Clin Infect Dis. 42(5), 614-21. https://doi.org/10.1086/500137

26. Naruszewicz-Lesiuk, D., Magdzik, W. (2000). Choroby zakaźne na ziemiach polskich w dwudziestym wieku. Przeglad Epidemiologiczny, 54(supl. 3), 5-9.

27. Piotrowska, A. (2009). Przypadek kontra człowiek. Focus Historia, 10, 38-40.

28. Thorvald, J. (1990). Dawna medycyna, jej tajemnice i potęga. Egipt, Babilonia, Indie, Chiny, Meksyk, Peru. Warszawa: Ossolineum.

29. Weiner, M., Kubajka, M. (2015). Tularemia - serious zoonotic disease. Health Problems of Civilization, 9(1), 39-46. https://doi.org/10.5114/hpc.2015.57104

30. World Health Organization. (2017). World Malaria Report. Pobrano z: (http://apps.who.int/iris/bitstream/handle/10665/259492/9789241565523-eng.pdf?sequence=1)

31. World Organisation for Animal Health, World Health Organization, Food and Agriculture Organization of the United Nations (2008). Anthrax in humans and animals. 4th ed. Geneva: World Health Organization. Pobrano z: (http://apps.who.int/iris/bitstream/10665/97503/1/9789241547536_eng.pdf)

32. Wheelis, M. (2002). Biological warfare at the 1346 siege of Caffa. Emerg Infect Dis. Center for Disease Control. 8(9), 971-75. https:/doi.org/10.3201/eid0809.010536

33. Zieliński, K.W. (2010). Patologia obrażeń i schorzeń wywołanych współczesną broniq $w$ działaniach wojennych i terrorystycznych. Warszawa: MON. 